\section{Losing the fat of the land}

The burning images on television and film - of tropical trees falling, bulldozers, and chainsaws-capture the very real loss of forests around the world. Yet there is a more insidious, and perhaps more pervasive peril, one that has not been captured by the photographic image: the wildlife in those tropical forests is being systematically lost. For subsistence and for commerce, people are hunting out the large mammals, birds and reptiles. The sheer number of animals being taken every year is staggering: 100,000 tonnes of wild meat annually culled from the forests of Amazonia, perhaps 10 times that from the forests of the Congo Basin. Millions and millions of individual animals. The process cannot be captured by an image so dramatic as a falling tree, but the end result is equally bleak - a forest stripped of its wildlife, 'defaunated' is the academic term, an empty forest devoid of bird song and shufflings in the underbrush.

How could we have come to this pass? Surely people have lived in these forests for tens of thousands of years, subsisting on wildlife, and selling furs, leather, meat and feathers to local markets? Yes, they have and they continue to do so, but forests over the last decades have been integrated into national societies, and into our global economy. The forests have been opened up by national authorities, and by logging, petroleum and mining companies. This opening-up has allowed both access to outsiders and transport of commodities from the forest. Human populations in the forests have increased through immigration and growth. Hunting technologies and practices have changed - the shotgun has replaced the spear. Forest communities have become more sedentary, and their weight on the land has steadily increased. The wild meat trade in particular has become vastly commercialized. The demand for wildlife meat from urban centres has climbed, as has demand for speciality wildlife products from international markets. The wildlife loss is already far advanced in the tropical forests of the Philippines, South East Asia and West Africa. It is dramatically under way in Indonesia, the Malaysian states of Sarawak and Sabah, central Africa and Amazonia.
The result? Forests devoid of seed dispersers, pollinators, and predators. Devoid of all large animals. Last month I visited at the Lambir Hills National Park in Sarawak-a forest preserve set up to protect perhaps the greatest floral diversity found anywhere on earth. Now an island of tropical forest in an altered landscape, the park has lost all of its large mammal and bird species to hunting. How will this now static forest degrade? What will we lose? And the consequences to forest-dwelling people and national economies are equally profound. The great outflow of wild meat from the forests has fed the people of many developing countries, and in so doing, is subsidizing and has subsidized national development. But now the source is drying up, and people across the tropics are losing an important source of animal protein.

This need not be another conservation disaster. The demand for wild meat and animal products can be curtailed and regulated. In Sarawak, for instance, the state government has imposed a total ban on all commercial hunting and sale of wildlife products in towns, while continuing to allow rural peoples to hunt for their subsistence. Even though local people lose a source of income, this is a move they support, for they have recognized the loss of their wildlife. There are also efforts supported by conservationists to find economically and socially viable alternative sources of animal protein for the rural peoples of the tropics - fish farms, cattle and pig production all have the potential to take the pressure off the forest. In addition, there are renewed efforts to manage wildlife populations in tropical forests. For instance, in Tahuayo-Tamshiyacu in Peru, local communities, with the help of international organizations, scientific institutions and government agencies, are monitoring and regulating the harvest of wildlife. These efforts, however, remain the exception rather than the rule, in part because the magnitude of the problem remains largely unrecognized. Yet these models indicate the way forward, and give us hope that the tropical forests that we are able to protect will be more than just trees.

John G. Robinson 